agreement as to the official findings may still be heard today.

Stress-corrosion by liquid metals takes place far more commonly than was recognised two decades ago: the subject has been comprehensively reviewed by M. H. Kamdar (Prog. Mater. Sci., 15, 289-374; 1973). Generally, such attack is not pronounced at or near ambient temperature, and it is thus a form of brittle fracture, enhanced by adsorption of the contaminant at the root of surface cracks. Some trace metals embrittle a variety of solid metals: thus mercury embrittles aluminium, zinc, cadmium, iron, silver, titanium and others, gallium attacks most of these metals (most spectacularly, aluminium), whereas bismuth only embrittles copper, and cadmium only iron and titanium. Mercury can claim championship status as a general trace nuisance in biology and engineering alike!

A paper by $W$. T. Grubb in this issue of Nature (Grubb, page 36) adds a further example to the growing number of instances of liquid metal embrittlement. It resembles the stainless steel/zinc syndrome in that the embrittlement is specific to hightemperature stressing and does not arise at room temperature, unlike the general run of such cases. Grubb has discovered that zircaloy-2 (a zirconiumbase alloy containing 1.5 at. $\%$ tin and small amounts of iron, chromium, nickel and oxygen, which has long been used to enclose fuel elements in watermoderated nuclear reactors) is embrittled by traces of metallic cadmiumsolid, liquid, or dissolved in another liquid metal-in the narrow temperature range $300-340^{\circ} \mathrm{C}$. The fracture is purely brittle in character under these circumstances and takes place by cleavage on the (hexagona1) basal plane. The report is clearly preliminary and there is as yet no information about the time during which stress must be applied to generate fracture: it is a frequent characteristic of stresscorrosion that fracture is delayed.

This finding follows the discovery, ten years ago, that iodine can cause stress-corrosion failure in zircaloys (there are several variants of the alloy) in the range $250-500{ }^{\circ} \mathrm{C}$. J. C. Wood (J. Nucl. Mater., 45, 105; 1972) studied the matter in detail for zircaloy held at $300{ }^{\circ} \mathrm{C}$, which is a typical reactoroperating temperature for water reactors. For adequately large stresses and surface concentrations of iodine, fracture ensued, but previous anneals to remove residual internal stresses greatly reduced its incidence. Iodineembrittlement is of peculiar concern because iodine, a volatile element, is a major fission product and is thus created inside the fuel element during service. Other fission products, however, would be expected to 'getter', that is, neutralise any free iodine; different metals can be regarded as being in competition for the attentions of free iodine. There was, in 1972 , no clear evidence that any cracks in fuel element containers had been caused by this mechanism, and I have seen no later papers to suggest that any such events had been established. Wood's paper pointed the way to a number of precautionary measures.

Cadmium-embrittlement of zircaloy might conceivably be of consequence in a nuclear reactor because cadmium is one possible constituent of neutronabsorbing control rods, and Grubb's discoverv may serve to discourage the use of this particular neutron absorber.

More generally, it is now clear that liquid metal embrittlement (if we may regard iodine as an honorary metal for present purposes) falls into two clearly distinct categories: hot or creep embrittlement, and cold embrittlement. It will be the next task of background research in this field to establish the characteristics of aggressor/victim combinations that predisnose a svstem to one of these two modes of attack. $\square$

\title{
Economics of aggression
}

\section{from John Krebs}

THe idea that cultural and genetic evolution are analogous is not new: both processes consist of the survival of a few out of many possible competing entities-ideas in the former case, genes in the latter. Some anthropologists and biologists have used this obvious parallel to develop the argument that human cultural traditions, like genes, have survived because they are adaptive (Harris, Culture, People, Nature; An Introduction to General Anthropology, Crowell, New York,
1971; Blurton-Jones, in Growing Points in Ethology, Cambridge University Press, 1976). The difficult question is to decide what is meant by adaptive. In the case of genes the answer is easy: successful genes survive because their individual owners are good at surviving and reproducing (Dawkins, The Selfish Gene, Oxford University Press, 1976), but do cultural traditions survive for the same reason? Most discussions by ecological anthropologists have emphasised group survival as a criterion of success of cultural traditions, which goes against the intuition of an evolutionary biologist well schooled in the view that differential survival of groups is not important in genetic evolution.

Recently W. H. Durham ( $Q$. Rev. Biol., 51, 385; 1976) has discussed the cultural evolution of traditions of intergroup warfare in man, attempting to analyse the problem in terms of costs and benefits to individuals rather than groups. In animals, aggression is almost invariably associated with competition for resources such as food and mates, and whether or not fighting evolves as a means of competition depends on the costs and benefits to individuals (see below). Resources which are too widely scattered to be economically defendable are not usually exploited by aggressive competition. Durham suggests that this may be why Eskimoes living off migrating caribou and salmon have little tradition of intergroup hostilities, while those in South West Alaska living off more reliable sources of game do have traditions of intergroup warfare. In considering group conflicts, Durham argues that the payoffs to an individual will vary with the group size. A larger group will have more chance of winning, but there are more individuals to share out whatever resource is captured through the victory. Although the details may be complex, these tradeoffs will lead to an intermediate optimum group size from the point of view of an individual in the group.

Durham discusses the example of the Mundurucu of Brazil in detail. These people traditionally lived in villages of about 200 individuals and engaged in intergroup warfare, collecting heads of rival villagers as trophies. The classical anthropological interpretation of this practice is that head hunting was a

\section{Correction}

In the report "Control systems in higher plants" (News and Views, 264, 214; 1976) work of Daphne J. Osborne and coworkers was incorrectly described. The last sentence of paragraph 1 , page 215 should read: "The rate of germination of normally slow (low vigour) embryos is however increased by a preliminary hydration, because during this period part of the early stage of germination is achieved. The biochemical changes are maintained when the embryo is dried again, so that when next supplied with water, such embryos complete germination more quickly, or are said to be 'enhanced'. In other words, if this treatment is given to whole seeds, a higher percentage will then emerge above the soil." 